\title{
LEPTOSPIROSIS OUTBREAK IN DAIRY CATTLE DUE TO LEPTOSPIRA SPP. SEROVAR CANICOLA: REPRODUCTIVE RATES AND SEROLOGICAL PROFILE AFTER TREATMENT WITH STREPTOMYCIN SULFATE
}

\author{
M.E. Genovez ${ }^{1}$, C. Del Fava ${ }^{1}$, V. Castro', T.B. Gotti ${ }^{1}$, C.C. Dib ${ }^{2}$, C.R. Pozzi², \\ J.R.P. Arcaro ${ }^{2}$, S. Miyashiro' ${ }^{1}$, A.F.C. Nassar ${ }^{1}$, S.L. Cirillo ${ }^{3}$
}

${ }^{1}$ Instituto Biológico, Centro de Pesquisa e Desenvolvimento de Sanidade Animal, Av. Cons. Rodrigues Alves, 1252, CEP 04014-002, São Paulo, SP, Brasil. E-mail: genovez@biologico.sp.gov.br

\begin{abstract}
The objectives of the present trial were to evaluate the reproductive parameters in a Holstein bovine herd affected by leptospirosis during the outbreak of abortion and stillborn fetus and treated with streptomycin sulfate. Animals were divided in 2 groups of 10 cows each: G1, treated with streptomycin sulfate $25 \mathrm{mg} / \mathrm{kg} / \mathrm{lw}$ for 3 days by IM route; and; G2, untreated control. Serum samples were collected on the onset of abortions and after that every 15 or 30 days until completing 270 days. Samples were analyzed by means of MAT - microscopic agglutination test that showed sera conversion to serovar Canicola with titers ranging from 100 to 51,200; 7/20 of the urine samples were positive for Leptospiraspp. by PCR After streptomycin sulfate therapy, the outbreak ended and urine samples also got negative to PCR and no fetus samples were positive in either techniques. However, it did not influence the evolution in antibody titers of serological profiles in both groups, which got negative after around 200 days of the onset of symptoms. Although there was no significant difference of the frequency of pregnancy/AI and calving/pregnancy rates between treated and untreated groups $(p>0.05)$, reproductive rates were lower in the untreated group.
\end{abstract}

KEY WORDS: Leptospirosis outbreak, dairy cattle, reproductive rates, streptomycin treatment, serological profile.

RESUMO

SURTODELEPTOSPIROSEEMREBANHOBOVINOLEITEIROINFECTADOCOMLEPTOSPIRA SPP. SOROVAR CANICOLA: TAXAS REPRODUTIVAS E PERFIL SOROLÓGICO APÓS TRATAMENTO COM SULFATO DE ESTREPTOMICINA. O presente trabalho objetivou avaliar o efeito do tratamento com sulfato de estreptomicina sobre o perfil sorológico de um rebanho bovino acometido de um surto de leptospirose pelo sorovar Canicola e avaliar os parâmetros reprodutivos no ciclo reprodutivo subseqüente. Foram formados 2 grupos de 10 fêmeas bovinas: G1- tratado com sulfato de estreptomicina, $25 \mathrm{mg} / \mathrm{kg} / \mathrm{pv}$ por 3 dias, via IM; G2 sem tratamento. Amostras de soro foram colhidas no início dos abortamentos e posteriormente a cada 15 ou 30 dias num total de 270 dias e examinadas pela reação de soroaglutinação microscópica-SAM. Vinte amostras de urina colhidas no início dos sintomas e 10 -15 dias após tratamento e seis fetos abortados (rins, fígado, pulmão e conteúdo abomasal) foram submetidos ao exame bacteriológico para pesquisa de bactérias causadoras de abortamento eà técnica de PCR paraLeptospiraspp. Ocorreu soroconversão predominante para Leptospiraspp. sorovar Canicola (títulos: 100 a 51.200); $7 / 20$ amostras de urina foram positivas para Leptospira spp. na PCR, sendo todas negativas no exame bacteriológico e nenhuma amostra fetal foi positiva em ambas as técnicas. Os abortamentos cessaram após a antibioticoterapia, e as amostras de urina negativaram-se na PCR. O sulfato de estreptomicina foi eficaz na eliminação da doença, entretanto, não influenciou a evolução dos títulos de anticorpos no perfil sorológico quando comparado ao grupo controle, ambos negativando-se ao redor de 200 dias após o início dos sintomas. Embora não houvesse diferença estatística entre as taxas de

\footnotetext{
${ }^{2}$ Instituto de Zootecnia, Centro de Análise e Pesquisa Tecnológica do Agronegócio de Bovinos de Leite, Nova Odessa, SP, Brasil.

${ }^{3}$ Vallée Saúde Animal, São Paulo, SP, Brasil.
} 
prenhez/IA e parto/ prenhez do grupo tratado em relação ao não tratado ( $p>0,05)$, talvez devido ao baixo número amostrado, as taxas reprodutivas foram menores no grupo não tratado.

PALAVRAS-CHAVE: Leptospirose em gado leiteiro, desempenho reprodutivo, perfil sorológico, tratamento com estreptomicina.

\section{INTRODUCTION}

Leptospirosis is characterized by cyclical dissemination of Leptospira spp. within species or groups of animals, where the acute infection affected, convalescent or carrier animal transmits it to susceptible one. Any serovar may infect any animal species, but actually a limited number of serovars affects productive species in an incidental manner, leading to outbreaks of abortion, stillborn fetus and return to estrus (FAINE et al., 1999). The objectives of the present trial were to establish the serological profile post treatment with streptomycin sulfate in a bovine dairy herd during the onset of leptospirosis caused by Leptospira interrogans serovar Canicola and evaluate the reproductive performance.

\section{MATERIAL AND METHODS}

An experimental Holstein bovine herd of Instituto de Zootecnia, Nova Odessa State of São Paulo, Brazil, composed by 120 dairy cows, was affected by an abortion and stillbirth outbreak. This herd had never been vaccinated against leptospirosis and the animals were seronegative for IBR/IPV, BVDV and Brucelosis. Lactating females were kept in a free stall, and heifers, pregnant animals and dry cows were kept in pastures of Panicum maximum cv. Tanzania grass, with rotational grazing, and received forage supplementation during winter (sorghum silage and chopped sugarcane), commercial concentrate feed and mineral salt ad libitum. Reproductive management was provided by artificial insemination with commercial semen certificated free of pathogens. Although it was a closed herd with rigorous transit control, it was located in a periurban area where wandering dogs and wild animals (capybaras) had access to the pastures and feeders.

The first abortion occurred in January / 2003 and its occurence increased until April/2003 when the herd presented a total of 12 abortions and stillbirth in 38 pregnant cows $(31.5 \%)$. At this time, leptospirosis diagnosis was confirmed by MAT. Twenty cows, being twelve Leptospira spp. serovar Canicola reactor ones with abortion or stillbirth history and eight reactor cows to the same serovar were selected and kept on two different pastures till the oncoming reproduction season (2004), when were inseminated with commercial semen. Two groups with 10 animals each were performed: G1treated with streptomycin sulfate $25 \mathrm{mg} / \mathrm{kg} / \mathrm{lw}$ for three days by IM route at 140 days since the abortion onset and G2- untreated control. Serum samples were collected on the onset of symptoms (abortion) and after that every 15 or 30 days until completed 270 days. Samples were analyzed by means of MAT microscopic agglutination test (FAINE et al.,1999) with 18 serovars of Leptospira spp. Twenty urine samples from both group were collected on the onset of symptoms and 10-15 days after treatment, as well as samples from 6 aborted fetuses (kidneys, liver, lungs, abomasal content). Samples were submitted to bacteriological examination for the study of abortioncausing bacteria (GeNovezet al., 1993;SCARCELLIetal., 2004) and to DNA amplification technique for Leptospira spp. by means of the polymerase chain reaction (PCR) using the sequence of the $16 \mathrm{~S}$ rRNA gene (Richtzenhain et al., 2002). During the following reproduction season (2004), the pregnancy/artificial insemination and calving/pregnancy rates between treated and untreated groups were collected. Statistical analysis was performed using Fisher's exact test with $95 \%$ confidence interval.

\section{RESULTS}

During the outbreak there was predominant seroconversion for Leptospira spp. serovar Canicola with titers ranging from 100 to 51.200. In January / 2003 the initial Canicola seroprevalence established on pregnant cow group was $2 / 38(5.2 \%), 4 / 38$ $(10.5 \%)$ in March/ 2003 and 14/38 (38.8\%) in May/ 2003.

Of the 20 urine samples, seven were positive for Leptospira spp. by PCR (Fig. 1) showing a $331 \mathrm{bp}$ amplified fragment(MérIENetal.,1992) butall samples were negative in the bacteriological examination. No fetus sample was positive in either technique.

Geometric mean and standard deviation of MAT serological titers of this dairy herd during theLeptospira spp. sorovar Canicola outbreak did not show any difference between treated and untreated groups (Table 1) (Fig. 2). Frequency of artificial insemination/ pregnancy and calving/pregnancy rates presented lower results in untreated group, although not statistically significant (Table 2). 
Table 1 - Geometric mean and standard deviation of MAT serological titers in a dairy herd after a Leptospiraspp. sorovar Canicola outbreak, according to group. São Paulo, 2005.

\begin{tabular}{lccccccccc}
\hline Days & 0 & 90 & 120 & $140^{* *}$ & 155 & 170 & 200 & 230 & 260 \\
\hline Treated group & $0.50 \pm 1.12$ & $0.32 \pm 1.06$ & $2.79 \pm 0.75$ & $1.93 \pm 1.72$ & $1.71 \pm 1.43$ & $1.18_{ \pm} 1.40$ & $1.26 \pm 1.26$ & 0 & 0 \\
Untreated group & $0.55_{ \pm} 1.16$ & $1.07_{ \pm} 1.43$ & $2.40 \pm 1.03$ & $1.47_{ \pm} 1.29$ & $1.67 \pm 1.21$ & $1.21_{ \pm} 1.30$ & $1.21_{-}^{+1.31}$ & 0 & $0.20 \pm 0.70$ \\
\hline
\end{tabular}

*Treated with $25 \mathrm{mg} / \mathrm{kg} / \mathrm{lw}$ for three days, by IM route.

${ }^{* *}$ Day of treatment.

Table 2 - Frequency of Artificial Insemination followed by pregnancy and calving in a dairy herd after a Leptospira spp. serovar Canicola outbreak according to group. São Paulo, 2005.

\begin{tabular}{lcccccccc}
\hline & \multicolumn{2}{c}{ Pregnancy/AI } & & \multicolumn{2}{c}{ Calving/Pregnancy } & & \multicolumn{2}{c}{ Abortion } \\
\cline { 2 - 3 } & 2003 & 2004 & & 2003 & 2004 & & 2003 & 2004 \\
\hline Treated group* & $7 / 9(77.8 \%)$ & $6 / 9(66.7 \%)$ & & $7 / 7(100 \%)$ & $5 / 6(83.3 \%)$ & & 0 & 1 \\
Untreated group & $6 / 11(54.5 \%)$ & $5 / 12(41.7 \%)$ & & $5 / 6(83.3 \%)$ & $4 / 5(80 \%)$ & & 1 & 1 \\
\hline
\end{tabular}

*Treated with $25 \mathrm{mg} / \mathrm{kg} / \mathrm{lw}$ for three days, by IM route. Not significant with $\mathrm{p}>0.05$.

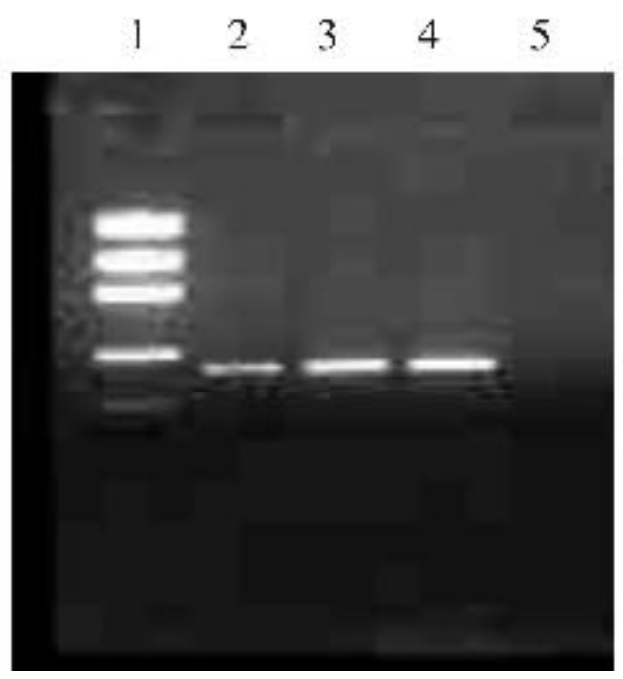

Fig. 1 - PCR for Leptospira spp.: 1- Low DNA Mass Ladder (100-2000 pb); 2- Cow 192 urine; 3- Cow 74 urine; 4Positive control (Leptospirainterrogans serovar Canicola); 5- Negative control -water.

\section{DISCUSSION}

The most common sign of bovine leptospirosis is the fail on reproductive performance: abortion, stillbirth and weak calves. Leptospirosis diagnosis based only on bacteriological culture from aborted foetus samples is not frequently successful, because the fetal expulsion occurs $24-48$ hours after its death, and it is already contaminated with ubiquitary and faster growth bacteria. In this case, althoughLeptospira spp. was not isolated from aborted fetus, the high sera conversion rates in many animals of this herd, the four-fold or more in antibody rise titers to Leptospira spp. serovar Canicola during serological monitoring and also the efficacy of antibiotic therapy, confirmed the leptospirosis course. MAT is considered a specific test for diagnosis of the infecting serovar or closely antigenically related serovar, thus the high sera prevalence associated to high titer (51.200) to serovar Canicola could be the cause of this reproductive disorders.

Although it has been declared that PCR is able to detect minimal quantity of DNA from any microorganism in all kind of biological sample, the processing is critical and must be adjusted to the tissue, fluid and species being tested. Many substances present in various types of clinical material inhibit $\mathrm{PCR}$, therefore positive specimens could beundetected because of false-negative results (LucCHEsiet al., 2004). Taq polimerase inhibitors such as chelation of free magnesium ions, hemoglobin, bile salts, acidic polysaccharides from glycoproteins, extreme $\mathrm{pH}$ variations, the phenol and chloroform often used for DNA extractionand purificationareconsidered critical. Some bacteria can be lysed during the storage of the tissue and, as a result, their DNA can be lost with the supernatant after centrifuging to concentrate the microorganisms. As leptospire is very sensitive to acid $\mathrm{pH}$ (6.8 or lower), putrefacted sample from aborted foetus could result negative and explained this fail. ( $\mathrm{BE}$; Mahbubani, 1994;Greenfield; White, 1993; Lucchesietal., 2004; Mahbubani; Bej,1994; Panaccio, 1994).

Streptomycin sulfate showed to be efficient in the elimination of the bacteria from the urinary tract as urine samples got negative by PCR. However, treatment did not influence the evolution of antibody 


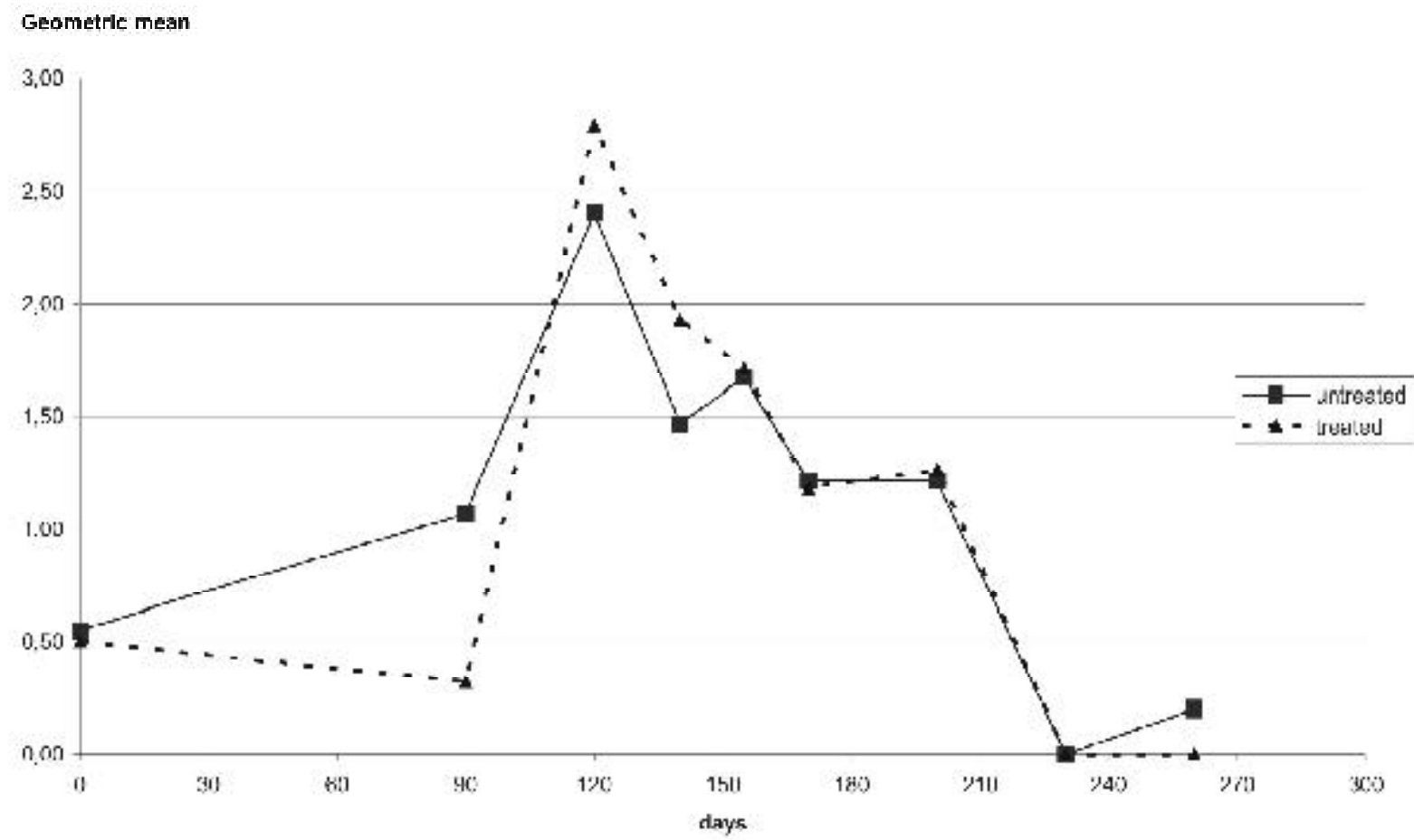

Fig. 2 - Geometric mean of MAT titers for Leptospira spp. serovar Canicola.

titers of serological profiles in both groups, which got negativeafter around 200 days of the onset of symptoms (Table1) (Fig. 2). Many practitioner veterinaries believe that antibody titers quickly decrease after some days from antibiotic therapy, and the MAT titer must be negative or much lower than before. These results have shown that MAT is not useful as a test for treatment efficacy control due to the long persistency of antibodies.

Maybe because of the small number of animals tested, there was no significant difference of AI/ pregnancy/and calving/pregnancy rates between treated and untreated groups ( $p>0.05$ ) (Table 2). Reproductive rates were lower in the untreated group, sothehypothesis thatleptospirescontinued interfering in reproductive performance of the untreated group until the next insemination season cannot be discarded. Leptospires may have been installed in preserved antibody sites and probably affected reproductive rates. Further studies on larger animal groups must be performed.

\section{REFERENCES}

BEJ, A.K.;M AhBUBANI, M.H. Thermostable DNA polymerase for in vitro DNA amplification. In:GRIFFIN, H.; GrIFFIN, A. (Eds.). PCR technology: current innovations. London: CRC Press, 1994. p.219-237.
Faine, S.; Adler, B.; Bolin, C; Perolat, P. Leptospira and leptospirosis. 2.ed. Melbbourne: MediSci, 1999. 272p.

Genovez, M.E.; Scarcelli, E.; Rojas, S.; Giorgi, W.; Kaneto, C.N. Isolamentos bacterianos de fetos abortados bovinos examinados no Instituto Biológico de São Paulo, no período de 1985 a 1992. Brazilian Journal of Veterinary Research Animal Science, v.30, p.107-112, 1993.

GREENFIELD, L.; W hite, T.J.Sample preparation methods. In: Persing, D.; Smith, T.; Tenover, F.; White, T.J. (Eds.). Diagnostic molecular microbiology: principles and applications. Washington DC: ASMPress, 1993.p.122137.

Lucchesi, P.M.A.; Arroyo; Gulllermo, H.; Etcheverría; Analía; Parma, A. E.; EIjo, A.C. Recomendações para detecção de Leptospira em urina pela PCR. Revista da Sociedade Brasileira de Medicina Tropical, v.37, n.2, p.131-134, 2004.

Mahbubani, M.H.; Bej, A.K. Applications of polymerase chain reaction methodology in clinical diagnostics. In: Griffin, H.; GrIFFIN. A. (Eds.). PCR technology: current innovations. London: CRCPress, 1994. p.307326.

Mérien, F.; Amouriaux, P.; Perolat, P.; Baranton, G.; Saint Girons, T. Polymerase chain reaction for detection of Leptospira spp. in clinical samples. Journal of Clinical Microbiology, v.30, p.2219-2224, 1992.

Panaccio, M.; Lew, A.M. Direct PCR from whole blood using formamide and low temperatures. In: GRIFFIN, H.; Griffin. A. (Eds.). PCR technology: current innovations. London: CRC Press, 1994. p.151-157. 
Richtzenhain, L.J.; Cortez, A.; Heinemann, M.B.; Soares, R.M.; SAKAMOTO, S.M.; VASCONCELlOS, S.A.; Higa, Z.M.; SCARCElli, E.; Genovez, M.E. A multiplex PCR for the detection of Brucella spp. and Leptospira spp. DNA from aborted bovine fetuses. Veterinary Microbiology, v.87, p.139-147, 2002.

Scarcelli, E.; Patti, R.M.; Cardoso, M.V.; MiYashiro, S.; Campos F.R.; Teixeira, S.; Castro, V.; Genovez, M.E.
Detecção dos principais agentes bacterianos causadores de abortamento em bovinos, período 20002002. Revista Brasileira de Reprodução Animal, v.28, p.2327, 2004.

Received on $13 / 7 / 06$

Accepted on 19/9/06 